\title{
Analysis of Testis Morphology and Sperm Parameters of Esox lucius (pike) from the River Danube
}

\author{
Stefanov Rossen and Desislava Abadjieva*
}

Institute of Biology and Immunology of Reproduction, BAS, Bulgaria

\begin{abstract}
Pike are an important species and declines are a concern, because the species provides predatory balance to many lake ecosystems. The aim of the current study was to examine the testicular morphology and sperm parameters of the freshwater fish Esox lucius (pike). The present study was carried out on 18 male fish, species Esox lucius, which were captured from the beginning of September until of October, throughout the Danube River. Samples were processed for routine semen assessment by sperm class analyzer and light microscopy. Histological testis' structure follows the general pattern described for other fishes. These descriptions are important for a better understanding of reproductive biology and phylogeny, for which data remain scarce in the literature. Middle sections of the testes were fully filled with spermatozoa different of other two parts as these results correspond with sperm motility. It can be concluded that recommended for insemination to use sperm from middle testicular part of Esox lucuis.
\end{abstract}

Keywords: Pike; Histology of testis; Motility

\section{Introduction}

The pike (Esox lucius) is one of the most important predatory fish species in Bulgaria. It's one of the preferred fish by anglers worldwide and contributes to the ecological balance of freshwater ecosystems. Its propagation and pond rearing has great traditions in the country, but insemination is difficult. The major problem of artificial fertilization of the pike is that the amounts of sperm which can be stripped are limited or the numbers of spermatozoa are insufficient due to premature activation of motility [1]. Sperm motility is functional parameter on male gametes, which enable spermatozoa to active move and to penetrate into female gametes. Duration of sperm motility in most fish species takes about $30 \mathrm{sec}$ to several minutes [2].

Sperm of fresh water fish are still in the reproductive organs and have a similar osmolality like as of seminal plasma. Physiological changes that occur with their activation is controlled by the endocrine system, which regulates spermatogenesis [3]. In addition, the reproductive biology of pike is not well understood with respect to the functional morphology of the gonads in relation to sexual maturity. Although aspects of reproductive dynamics of Esox lucius has already been described in the literature, a detailed characterization of testis structure and sperm motility is still needed. Therefore, the aim of the present study was to examine the testicular structure and sperm motility of the freshwater fish Esox lucius.

\section{Material and Methods}

\section{Fish samples}

The study was carried out on 18 male fish, species Esox lucius, which were captured from the beginning of September until of October. Sexually matured fish with weight $1810 \pm 0.60 \mathrm{~g}$ and length $64.3 \pm 2.14$ $\mathrm{cm}$ were caught in and along on right part of the Danube River, in Archar-Oris lowland, region around Montana, Bulgaria. Angling rods and natural baits or lures were used to collect pike. The length of the body fishes was measured to a precision of $1 \mathrm{~cm}$, and the weight to a precision of $50 \mathrm{~g}$.

Fish were sacrificed by serving the spinal cord anterior to the dorsal fin and the testes were dissected out using sharp scalpel blades and clean dissection tools. The pike were measured with a precise scale and ruler.

\section{Gross-morphometric measurement}

Testicular weight and length were measured and Gonado-Somatic Index was calculated by the following formula [4]:

GSI $=($ Gonad weight $/$ Total body weight $) \times 100$

\section{Analysis of testis morphology}

Specimens included all parts of the testis from anterior through middle to posterior parts were fixed in $10 \%$ buffered formalin for $24 \mathrm{~h}$, dehydrated in alcohol, cleared in xylene and embedded in paraffin. The serial cross sections $(5 \mu \mathrm{m})$ were obtained using Leica microtome (2125RT) and stained with periodic acid shiff's reagent (PAS; Sigma) and examined by light microscopy Olympus BX51 (Tokyo, Japan).

\section{Analysis of sperm parameters}

The testes were then cut into slices of about $0.5 \mathrm{~cm}$ and squeezed through a $150 \mu \mathrm{m}$ mesh to collect $1.5-2 \mathrm{ml}$ of testicular sperm per individual in Eppendorf tubes. The time lapse from collection of sperm to analyses was $30 \mathrm{~min}$. Testicular sperm samples were activate with distilled water and submitted to routine semen assessment by sperm class analyzer (SCA, Microptic S.L., Barcelona, Spain) to determine the sperm concentration $(\times 106 / \mathrm{mL})$ and total sperm motility $(\%)$ of spermatozoa.

Data were evaluated using the computer program Excel 2007. Values are presented as mean \pm statistical error for each variable. Values were considered statistically significant by t-test of Student.

*Corresponding author: Desislava Abadjieva, Biology and Immunology of Reproduction BAS, 1113 Sofia, 73 Tzarigradsko shosse, Bulgaria, Tel: 3598888714036; E-mail dessi_l@abv.bg

Received July 23, 2015; Accepted October 12, 2015; Published October 14 2015

Citation: Rossen S, Abadjieva D (2015) Analysis of Testis Morphology and Sperm Parameters of Esox lucius (pike) from the River Danube. J Cytol Histol S3:017. doi:10.4172/2157-7099.S3-017

Copyright: @ 2015 Rossen S, et al. This is an open-access article distributed under the terms of the Creative Commons Attribution License, which permits unrestricted use, distribution, and reproduction in any medium, provided the original author and source are credited. 


\section{Results and Discussion}

\section{Morphological and histological structure of testis}

The testes of mature Esox lucius were elongated, paired organs with a light brown color (Figure 1) located along the whole body: under the head immediately and posterior to the anus. Testis mean weight and length were $106.0 \pm 1.60 \mathrm{~g}$ and $26.0 \pm 0.95 \mathrm{~cm}$, respectively. The testicular GSI was $0.070 \pm 0.002 \%$.

The testis was covered on its exterior with a vascular connective tissue tunica albuginea, containing smooth muscle, elastic fibers and blood vesicles. The periphery of testis had a spermatic duct lined with cuboidal epithelium (Figure 2). The bulk of the testis was composed of seminiferous tubules. These seminiferous tubules were oriented at right angles to the long axis of the testis and they were ended blindly at its periphery (Figure 3 ).

The seminiferous tubules were filled with germinal cysts. The germinal cysts contained germinal cells at different stages of development. The testicular tubules were larger and were distended with different spermatogenic stages with the appearance of huge number of spermatozoa in their lumen. All stages of spermatogenesis were predominant, but they was different in separate parts. In anterior part the testicular tubules were surrounded by fusiform shaped myoid cells (Figure 4, arrows). The seminiferous tubules were filled with germinal cysts. It was notice the presence Leydig cells with polygonal shape. One of them was spermatogonia which give rise to different generation of spermatogenic cells in germinal cyst, while the other was Sertoli cells.

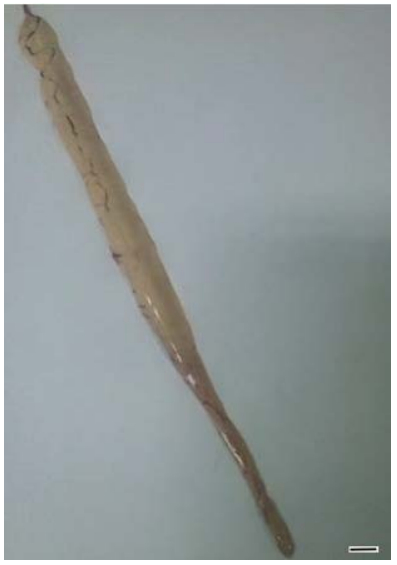

Figure 1: General aspect of Esox lucius testis (scale bar $=1 \mathrm{~cm}$ )

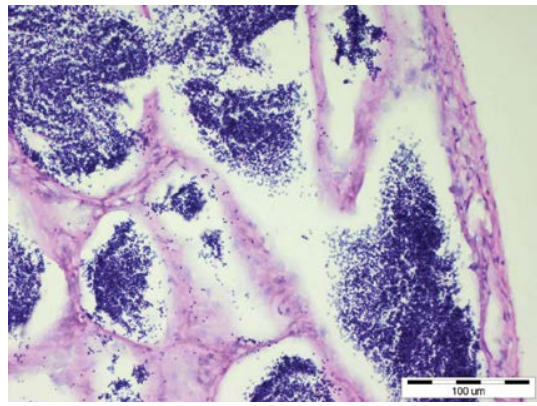

Figure 2: Section of testis of E. lucius showing: thin tunica albuginea (arrow), spermatogonia (Sg), spermatids (St), PAS (x40)

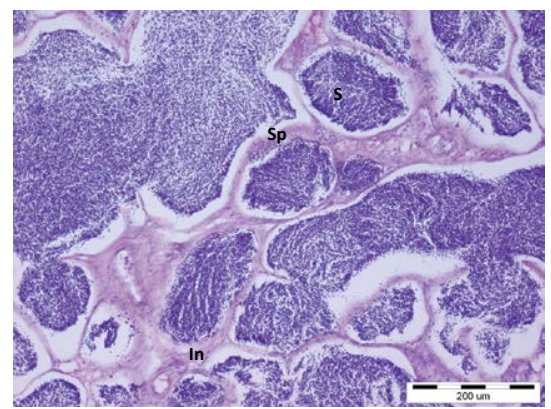

Figure 3: Section of testis of E. lucius showing: sperms (S), spermatogonia $(\mathrm{Sg})$, spermatocytes (Sc), interstitial tissues (In), (PAS, x20)

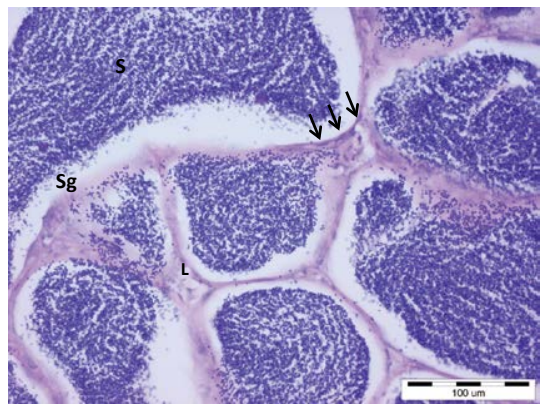

Figure 4: Section of testis of E. lucius showing: spermatogonia (Sg) sperms (S), Leydig cells (L), myoid cell around thetesticular tubule (arrow), (PAS, $x 40)$

Middle sections of the testes were fully filled with spermatozoa and separated by a thin layer of connective tissue with single spermatogonium cells (Figure 5A). The interstitium filled the intertubular spaces and was composed mainly of fine collagenous connective tissue which contained abundant interstitial Leydig cells and blood capillaries (Figure 5C).

In the posterior part, the structure of testes was clearly loosened and spermatozoa did not fill uniformly all the ampullae of the testes, leaving free spaces at their banks. The connective tissue was enlarged and numerous spermatogonium were observed (Figure 5B). The tubular lumen contained residual sperms. The posterior part showed different degrees of vacuolation. The Leydig cells were less in field occupation and smaller in size.

The anterior and posterior testicular parts were similar and secretory regions were found within the middle part, indicating that the testes of pike were devoid of seminal vesicles, despite spermatozoa were present in the lumen of the seminiferous tubules, after their releasing from the germinal cysts of the spermatids which exposed to modification to be transformed into spermatozoa.

\section{Sperm analyses}

Sperm motility was comparatively high and amounted to more than $75 \%$ in the middle part of testis (Table 1). In addition of this parameter, concentration of spermatozoa also was significant higher in middle part in comparison with anterior and posterior testicular parts. A statistically significant difference was not observed between anterior and posterior parts to both measures.

The coefficient of determination $\left(\mathrm{r}^{2}\right)$ calculated by ordinary least-squares regression, allowed us to define the regression line 


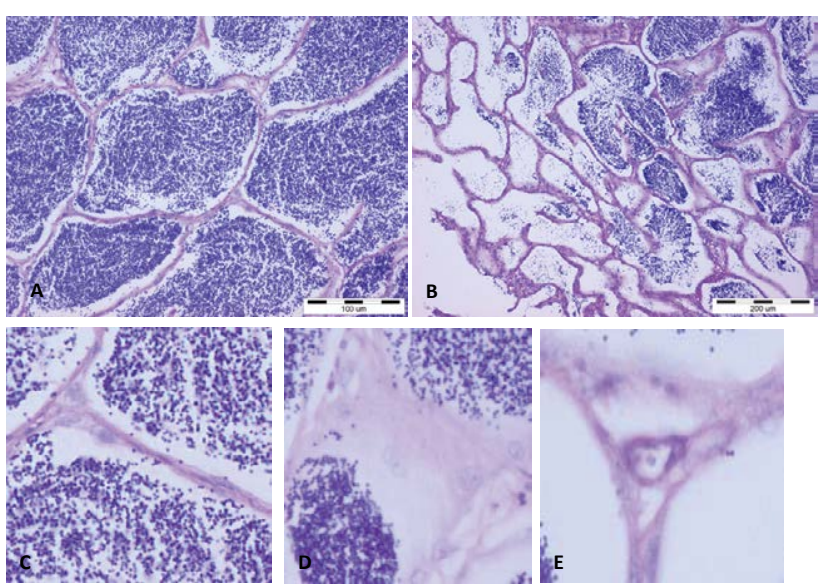

Figure 5: Structure of the mature pike testis (PAS): A. Middle sections of the testes (x40); B. Posterior part of testis (x20); C. Leydig cells $\left({ }^{*}\right.$, intermediate sized cells with a round-oval nucleus, $x 40)$; $D$. large solitary spermatogonium cells $\left({ }^{*}, x 40\right)$; E. Sertoli cells $\left({ }^{*}, x 40\right)$

\begin{tabular}{|c|c|c|c|}
\hline \multirow{2}{*}{ Parameters } & \multicolumn{3}{|c|}{ Part of testis } \\
\hline & Anterior & Middle & Posterior \\
\hline $\begin{array}{l}\text { Spermatozoa concentration, } \\
\qquad\left(\times 10^{9} \mathrm{ml}^{-1}\right)\end{array}$ & $18.40 \pm 1.10$ & $21.00 \pm 1.00^{*}$ & $18.60 \pm 1.08$ \\
\hline Total motility, $(\%)$ & $60.15 \pm 6.90$ & $78.0 \pm 6.61^{*}$ & $69.18 \pm 5.51$ \\
\hline \multicolumn{4}{|c|}{ The value mark off the star is significant: ${ }^{*}=P<0.05$} \\
\hline
\end{tabular}

Table 1: Data of semen analyses of male pike.

approximating at best the real data points. The effect of of the activating medium- filtrated river water was tested on the three sperm samples from different testis part. Significant correlations were observed between percent sperm motile from middle part and time, when sperm were activated with river water: $\mathrm{y}=-18.6 \operatorname{Ln}(\mathrm{x})+131.0 ; \mathrm{r}^{2}=0.88(P<$ $0.001)$. These data define the middle testicular part of pike as important for practical applications in artificial insemination and sperm storage.

\section{Discussion}

Sperm quality is a very important factor conditioning the correct process of natural or artificial spawning. Researches on the anatomy and physiology of the male reproductive system are important to better understand the biology of fish reproduction [5]. The present study examined the testicular structure and sperm parameters as concentration and motility in anterior, middle and posterior part of the testis of freshwater Esox lucius. Spermatogenesis in the annual cycle of some species is essentially different, e.g. spermatozoa in the male gonads of carp are present throughout the year [6], while in trout spermatozoa are present only in the reproductive period which occurs in autumn or in winter [7]. In some species there is an additional period after spawning in the annual reproductive cycle lasting 1-2 months. These observations were described in Eurasian perch testes and were confirmed in the present study. The lack of spermatids in the late part of spawning period in the testes of pike suggests a pause in the spermatogenesis process after the end of the reproductive season.
Sperm motility and concentration are parameters which determine the capacity of spermatozoa to fertilize. The proportion of motility spermatozoa is very high in middle section $(78 \%)$ and slightly lower in anterior and posterior part (60\% and $69 \%$, respectively). It's suggests that sperm motility of pike is inhibited due to high osmolality in the seminal plasma. Our data are similar to result of Tomasik and Sobocinski [8] that found $80 \%$ sperm motility in middle and posterior part, also slower sperm motility in anterior part of testis of rainbow trout. Authors concluded that the percent of fertilization of eggs regardless of the section of the testes which yields the spermatozoa. In addition, based on the sperm concentration we can indirectly infer about the correct or irregular function of males gonads. The sperm concentrations we identified in this study were similar to muskellunge Esox masquinongy [9] - a closely related species. In addition, concentration of spermatozoa could be a possible accessory quality indication, useful when selecting sperm samples appropriate for cryopreservation.

\section{Conclusion}

Pike are an important species and declines are a concern, because the species provides predatory balance to many lake ecosystems. Histological testis' structure follows the general pattern described for other fishes. These descriptions are important for a better understanding of reproductive biology and phylogeny, for which data remain scarce in the literature. Although it can be concluded that recommended for insemination to use sperm from middle testicular part of Esox lucuis. This study showed that sperm morphology can be used for fish classification. Interes for future investigation is sperm morphology, in particular, the flagellar part, which can show changes in motility.

\section{References}

1. Lahnsteiner F, Weismann T, Partner RA, (1998) An efficient method for ryopreservation of testicular sperm from the northern pike, Esox lucius $L$. Aquac Res 29: 341-347.

2. Billard R, Cosson J, Crim LW (1993) Motility of fresh and aged halibut sperm Aquat Living Resour 6: 67-75.

3. Nagahama $Y$ (1994) Endocrine regulation of gametogenesis in fish. Int J Dev Biol 38: 217-229.

4. De Vlaming VL, Grossman G, Chapman F (1982) On the use of gonadosomatic index. Comparative Biochemistry and Physiology 73: 31-39.

5. Furbock S, Patzner RA, Lahnsteiner F (2010) Fine structure of spermatozoa of Chondrostoma nasus and Rutilus meidingerii (Teleostei, Cyprinidae), as revealed by scanning and transmission electron microscopy. Acta Zoologica 91: 88-95.

6. Koldras M, Bieniarz K, Kime DE, (1990) Sperm production and steroidogenesis in testes of the common carp, Cyprinus carpio L., at different stages of maturation. Journal of Fish Biology 37: 635-645.

7. Billard R (1986) Spermatognesis and spermatology of some teleost fish species. Reprod Natr Dev 26: 877-920.

8. Tomasik L, Sobociński A (1987) Quality of rainbow trout (Salmo gairdner Rich.) spermatozoa collected from different sections of the vas defferens. Acta Ichthyol Piscat 17: 49-54.

9. Feng L, Liu L, Dabrowski K (1996) Characteristics of Muskellunge Spermatozoa I: Ultrastructure of Spermatoza and Biochemical Composition of Semen. Transactions of the American Fisheries Society 125: 187-195. 